doi $10.15826 /$ recon.2021.7.3.015

UDC 339.97, 37.015 .6

JEL I23, D61

\title{
The economic and organizational model of the international admission campaign during the COVID-19 pandemic (the case of the Moscow Institute of Physics and Technology)
}

\author{
A.D. Oykher \\ Moscow Institute of Physics and Technology, Moscow, Russia; anna.oykher@gmail.com
}

\begin{abstract}
Relevance. In the face of the COVID-19 pandemic, universities all over the world had to deal with a major challenge - transition from face-to-face to online learning. It was necessary to make this transition without damaging the quality of education and the transparency of examinations, especially entrance examinations taken by international students. The number of the latter fell significantly because of the pandemic and the competition for overseas students became especially fierce. One of the optimal solutions to the problem of conducting entrance exams during the pandemic was the online proctoring system.

Research objective. This research aims to assess the economic efficiency of the online proctoring system by looking at the case of the Moscow Institute of Physics and Technology (MIPT).

Data and methods. The article compares the most popular online proctoring systems on the market and used by universities in Russia and other country. Furthermore, it analyzes the results of the international admission campaign in 2020 and the economic effect of the in-house proctoring system in comparison with other readymade solutions.

Results. The research results showed that the MIPT's in-house proctoring system is no less efficient than the most popular readymade systems used by the majority of universities in Russia and worldwide, yet the costs of developing and operating the university's own system are significantly lower.

Conclusion. The development of an in-house online proctoring system can increase the economic efficiency of universities in terms of international admission in the forthcoming years.
\end{abstract}

\section{KEYWORDS}

online-proctoring, international admission, international students, admission campaign, economic efficiency, cost effectiveness, education abroad, blendedlearning, higher education

\section{FOR CITATION}

Oykher, A.D. (2021). The economic and organizational model of the international admission campaign during the COVID-19 pandemic (the case of the Moscow Institute of Physics and Technology). R-economy, 7(3), 170-178. doi: 10.15826/recon.2021.7.3.015

\section{Экономическая и организационная модель международной приёмной кампании во время пандемии COVID-19 (на примере МФТИ)}

\section{А.Д. Ойхер}

Московский физико-технический институт, Москва, Россия; anпа.oykher@gmail.com

\begin{abstract}
АННОТАЦИЯ
Актуальность. В условиях пандемии, начавшейся в 2020 г. в разгар кампании по приему иностранных студентов, вузы по всему миру столкнулись с серьезным вызовом - необходимостью перевода обучения и различных видов экзаменов в дистанционный формат. При этом было необходимо осуществить этот переход без ущерба для качества обучения и прозрачности проведения экзаменов. Кроме того, это было критично для вступительных и отборочных мероприятий для абитуриентов из-за рубежа, - так как их количество, ввиду существенного снижения спроса на обучение за рубежом, было существенно ниже вследствие пандемии, и, соответственно, конкуренция вузов за них была крайне высокой. Одним из наиболее оптимальных решений этой задачи является использование системы онлайн-прокторинга.
\end{abstract}

\section{КЛЮЧЕВЫЕ СЛОВА}

онлайн-прокторинг, набор иностранных студентов, иностранные студенты, приемная кампания, экономическая эффективность, рентабельность, образование за рубежом, смешанное обучение, высшее образование 
Цель исследования. Целью данного исследования было оценить экономическую эффективность использования системы прокторинга для университета при наборе иностранных студентов на примере Московского физико-технического университета (МФТИ).

Данные и методы. В статье был проанализирован опыт использования в вузах системы онлайн-прокторинга, проведено сравнение наиболее популярных систем, предлагаемых на рынке и используемых зарубежными и российскими университетами. Проанализированы итоги кампании по набору иностранных студентов в 2020 году и экономический эффект применения собственной системы прокторинга в сравнении с использованием готовых решений, предлагаемых на рынке.

Результаты. Результаты исследования показали, что применение собственной системы не уступает по функционалу наиболее популярным готовым решениям, услугам которых сегодня пользуется большинство университетов за рубежом и в РФ, при этом затраты на разработку и эксплуатацию собственной системы - существенно ниже и, что немаловажно, в основном не являются постоянными.

Заключение. Учитывая текущую эпидемиологическую ситуацию, результаты исследования показывают, что разработка собственной системы онлайн-прокторинга могут повысить для вузов экономическую эффективность набора иностранных студентов в ближайшие годы.

\section{FOR CITATION}

Oykher, A.D. (2021). The economic and organizational model of the international admission campaign during the COVID-19 pandemic (the case of the Moscow Institute of Physics and Technology). R-economy, 7(3), 170-178. doi: 10.15826/recon.2021.7.3.015

\section{Introduction}

The COVID-19 pandemic, which began in 2020, has become a real test for higher education systems around the world. For the first time in history, university education faced the threat of being put on hold for such a long period of time (without any certainty regarding how long this situation may last). Universities managed to continue their courses with the help of distance learning technologies (Huang et al., 2020, Grande-de-Prado et al., 2021). With the exception of subjects requiring laboratory or other special equipment (these subjects were moved to later semesters), almost every lesson was eventually moved online (Alessio \& Messinger, 2021, Johnson et al., 2021, Chung et al., 2020, Graham, 2019, Reedy et al., 2021).

However, the difficulties faced by universities and students and/or applicants were not limited to the educational process. There were other significant consequences of the pandemic and the general lockdown: these included rescheduling and cancellation of international events, for instance, partnership weeks and other significant networking events where real-life communication plays an important role (according to the EAIE, these effects were mentioned by $20 \%$ of respondents - representatives of European universities) (Rumbley, 2020). Other problems included difficulties in communication with internal and external partners (migration authorities, municipal authorities, partner universities, etc.) (mentioned by $16,9 \%$ of respondents) (Rumbley,
2020), an abrupt end to extracurricular activities and extracurricular interaction with other students, professors ${ }^{1}$, etc.

Despite the unpredictable epidemiological situation, according to the report of the Ministry of Science and Higher Education of Russia, almost every university showed its preparedness to mobilize and work in a new mode and thus maintain a sense of stability for the faculty and students (Klyagin et al. 2020). The most successful up-to-date practices of Russian universities of adapting their educational process to the reality of the pandemic are described on the website of the Association of Global Universities Keep on studying. Keep on teaching ${ }^{2}$. For instance, there is a website created by the St.Petersburg Electrotechnical University specifically to support applicants who have chosen difficult subjects for their final exams ${ }^{3}$. Other online solutions include the

${ }^{1}$ Lessons of the Stress Tests. Higher education during the pandemic and after. Analytical report made by university rectors and working groups (edited by Barannikov K.A et al.) (In Russ.) Retrieved from: https://www.hse.ru/data/2020/ 07/06/1595281277/003 \%D0\%94\%D0\%BE\%D0\%BA\%D0\%BB\%D0\%B0\%D0\%B4.pdf

${ }^{2}$ Resource for supporting students and professors of Russian universities Keep on studying. Keep on teaching in Russian). Retrieved from: https://od.globaluni.ru/keep-learning/ practices $/$ ? sectionId $=193$ \&page $=1$

${ }^{3}$ Case of supporting applicants in choosing traditionally complex subjects, platform solutions (Kupriyanov M.S., Chirtsov A.S., ETU “LETI") (In Russ.) Retrieved from: https:// od.globaluni.ru/upload/medialibrary/812/81240a4e3c90881claabeb2cc7769dec.pdf 
Digital Assistant of the ITMO University ${ }^{4}$, lecture broadcasting in virtual MIPT classrooms ${ }^{5}$, student navigator for distance learning of Immanuel Kant Baltic Federal University ${ }^{6}$, and so on.

A special place in the practices of Russian and international universities is occupied by online proctoring in conducting entrance and midterm exams. Proctoring is a procedure of monitoring and controlling remote exams (Jia \& He, 2021).

The purpose of this research was to assess the economic efficiency of the proctoring system for international admissions by using the case of the Moscow Institute of Physics and Technology (MIPT). This research objective determined the following tasks: first, to analyze the use of the online proctoring system in Russia and other countries; second, to identify the peculiarities of the online proctoring program developed by the MIPT in comparison with other systems used around the world; and, finally, to estimate the economic impact of the proctoring system during the international admission campaign at the MIPT in 2020.

\section{Background}

During the pandemic, the number of international applicants to Russian universities fell dramatically (this happened mostly for economic and psychological reasons), which made the competition for them even more fierce. This, in turn, made the problem of organizing entrance exams online and ensuring their transparency even more important.

According to the survey conducted by the International Association of Universities, one of the main problems faced by universities during the pandemic was the decline in the number of international applicants (this effect was mentioned by $46 \%$ of respondents) ${ }^{7}$. In the report of the website about education abroad Educations.com (The Impact of COVID-19 on Study Abroad: April 2020

${ }^{4}$ ITMO University Avatar Project is Now in Beta Testing (ITMO official website, A. Nikulina). Retrieved from: https:// news.itmo.ru/ru/science/it/news/9696/

${ }^{5}$ Watch live streams using virtual classrooms (MIPT official website, news section) (In Russ.) Retrieved from: https:// mipt.ru/education/elektronnoe-obuchenie/news/news200831

${ }^{6}$ Introducing a demo version of the navigator on distance learning for students of Immanuel Kant Baltic Federal University (Immanuel Kant Baltic Federal University official website, news section) (In Russ.) Retrieved from: https://kantiana.ru/ news/studencheskie/predstavlyaem-demoversiyu-navigatora-studenta-bfu-im-i-kanta-po-distantsionnomu-obucheniyu/

International Association of Universities. The Global Voice of Higher Education. Retrieved from: https://iau-aiu.net/ Covid-19-Higher-Education-challenges-and-responses
Survey Results, dated April 24, 2020) ${ }^{8}$, only 5,4\% of the respondents who had previously planned to study abroad answered that they wanted to go through with the admission; $13,5 \%$ planned to postpone their enrollment; $5,4 \%$ wanted to cancel the whole process; and 38,8\% found the question difficult to answer. These data clearly show that uncertainty, fear for one's health, difficulty in predicting how the situation will develop and many more factors significantly reduced the demand of international students and only $5,4 \%$ of those who had expressed their desire to study abroad before kept their decision. Therefore, universities had to switch to new models of student selection and teaching faster and more efficiently than their rivals (Kuh, 2005).

Apart from the difficulties associated with the transition to online learning, universities faced one more problem - the difficulty of ensuring transparent and fair entrance exams. In Russia, this problem was particularly urgent for midterm exams, final exams, diploma and thesis defense, and so on. This was also the case with entrance exams organized for overseas applicants since the vast majority of Russian students take the Unified State Exam, which serves both as school finals and as university entrance exam (Li et al., 2021). A study conducted by the Ministry of Science and Higher Education of the Russian Federation showed that more that $70 \%$ of respondents feared that the chances of cheating at online exams would be higher. A possible risk of dishonest behavior among students during online exams conducted without a special surveillance system was described in previous research (Dawson, 2015, Kitto \& Saltmarsh, 2007, Corrigan-Gibbs et al., 2015).

If face-to-face examinations were for some reasons impossible, universities actively used online testing systems (Collis \& Moonen, 2004, Shraim, 2019, Anderson, 2008). During the pandemic, these systems were successfully used not only by the leading Russian universities (e.g. the proctoring system of the ITMO University based on the National Open Education Platform ${ }^{9}$; the MIPT proctoring system ${ }^{10}$; OMV proctoring sys-

8 The Impact of COVID-19 on Study Abroad: April 2020 Survey Results (Abby Guthrie Svanholm). Retrieved from: https://institutions.educations.com/insights/student-surveycovid-19-and-study-abroad

${ }^{9}$ National platform for open education (Instructions for passing midterm and final attestations using ITMO proctor system) (In Russ.) Retrieved from: https://openedu.ru/proctoring-manual-itmoproctor/

${ }^{10}$ MIPT platform for online-testing. Retrieved from: https://exams.mipt.ru/ 
tem of Peter the Great St. Petersburg Polytechnic University ${ }^{11}$ ) but also by regional universities (e.g. the Vyatka State University used a proctoring system for defense procedures) $)^{12}$.

The Moscow Institute of Physics and Technology (MIPT) is a leading Russian university with a focus on training specialists in physics, mathematics, IT, biology, biomedical physics and related disciplines. The problem of selecting applicants from non-CIS countries has been relevant for a long time, first of all in terms of conducting entrance exams and to ensure transparent and efficient midterm testing. In order to solve this problem, at the initiative of the university's International Department, in 2019, an in-house proctoring system was developed.

Today, proctoring is actively used at universities around the world (Linden \& Gonzalez, 2021) - the COVID-19 pandemic and transition to distance learning forced universities to apply this technology on a larger scale - not only to international but also to local students (Grajek, 2020). Therefore, at present, the topic of the proctoring system usage at universities has become more relevant than ever, many publications of 2021 are dedicated to this topic (Raman, R. et al,2021; Kharbat, F.F., Abu Daabes, A.S., et al., 2021)

Today the most popular services used worldwide are as follows: ProctorUlive+ and Proctor Track Proctor Live AI (for real time monitoring); Proctorio, Proctor Urecord+ and review+, Respondus Monitor, Proctor Track Proctor Auto and QA, Integrity Advocate, Examity, HonorLock (for checking exams with post-review function) and TopHatTest (this service allows not only to automatically follow the activity on the student's personal computer (if there are any applications opened, etc.) this system, in our opinion, is ineffective and may be used for a limited number of tests).

In Russia, the company Examus has developed a service called Examus.Proctoring, which has practically monopolized the sector. There are a lot of leading Russian universities that coope-

${ }^{11}$ Polytechnic university introduced new monitoring system for online exams (Feature was prepared by SPbPU Department of Public Relations. Text by Raisa Bestugina) (In Russ.) Retrieved from: https://www.spbstu.ru/media/news/education/ polytech-new-system-monitoring-progress-online-exams/

${ }_{12}$ The first remote defenses of qualification work took place at Vyatka State University (Vyatka State University official website, news section) (In Russ.) Retrieved from: https://www. vyatsu.ru/internet-gazeta/v-vyatgu-proshli-pervyie-distantsionnyie-zaschityi.html?utm source $=$ BenchmarkEmail\&utm campaign=COVID-19 \%7c RU \%7c \%d0\%92\%d1\%8b\%d0\%bf\%d1\%83\%d1\%81\%d0\%ba 2\&utm medium=email rate with this company, such as the Higher School of Economics, Financial University, Ural Federal University, RANEPA and many others. The company offers three options for conducting exams: automatic (the system independently verifies the student's ID, observes their behavior, direction of their gaze, analyzes sound in the room, records violations on video and prepares reports); asynchronous (post-viewing video mode, which allows to check automatic notifications of the system about recorded violations); and synchronous (proctors monitor students in real time). The fundamental difference between the systems like Examus.Proctoring and the system implemented in the MIPT is that unlike ready-made tools, the in-house system of the MIPT is an entirely independent platform and does not depend on any third-party applications.

As mentioned above, the majority of universities use the first or second type of the system (it is obvious that the third method of conducting exams (with a live online proctor) is the most reliable but it is also the most expensive one and, therefore, the least profitable (Gourlay, 2021). The MIPT system, for its part, allows to conduct all three types of exams, however, it is used more often for exams with real-time monitoring and it is this function that has been constantly supplemented and improved. At present, the system can be used to conduct online surveillance of up to 20 participants for each proctor simultaneously, with an unlimited number of proctors. 200 participants can take a test simultaneously. The system provides a flexible configuration of the conditions display, prompts adding, auto-check setup, options generation. Thus, each event can be configurated as conveniently as possible, taking into consideration the specifics of each subject and requirements for a concrete exam, which would be impossible with a third-party system or it would cost so much money that it would be infeasible.

\section{Results}

The development of the MIPT proctoring system began in 2018, long before the start of the pandemic, and its goal, as we mentioned above, was to facilitate organization of entrance exams for international applicants. In 2019-2020, some improvements were still underway, for example, the interface was being improved, the functionality was refined, but in general, in 2019, the MIPT already had its own working proctoring system. Therefore, when the pandemic struck, the univer- 
sity did not have to search for any solutions for conducting distance exams and attestations - it was enough to simply scale up the existing system for the whole university. It is important to note that in accordance with the clause 5.4 of the MIPT's Admission Rules, entrance exams are conducted online if the ID of the applicant is verified. In other words, the system was ready for conducting any exams including entrance ones (for both international applicants and applicants from the Russian Federation). Overall, the university spent about 2.5 million of rubles on the creation of this system, which proved to be highly effective as it allowed to achieve a significant increase in the number of international applicants (see Fig. 1).

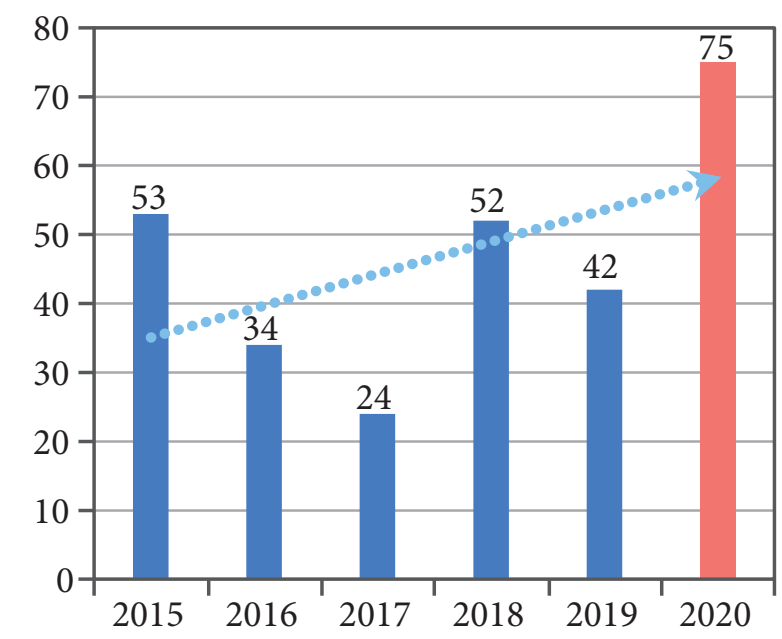

Figure 1. Number of fee-paying international applicants by years

Source: MIPT annual report on international admission for $2020 / 2021$

It is important to mention that in previous years, the tuition fee for international applicants was 435,000 rubles per year (for each level of education). However, due to the epidemiological situation in 2020 and the predicted decrease in the ability to pay in case of potential international applicants, the administration of the university decided to cut the cost of education (by $17 \%$ on average) and divide it depending on the level of education. As a result, in 2020, the cost of education for international Bachelor's students was 320,000 rubles; for Master's students, 350,000 rubles; and for $\mathrm{PhD}$ students, 375,000 rubles. In 2020, 75 international applicants were admitted to the MIPT on the contract basis, 22 Bachelor's students, 48 Master's and $5 \mathrm{PhD}$ students. Therefore, it is possible to count and compare the revenue from international applicants studying on the contract basis in 2015-2020.
Figure 2 shows that the revenue from international student enrollment in 2020 (despite the pandemic) grew by $41 \%$ in comparison with the previous year and by $44.5 \%$ in comparison with the average revenue from the previous 5 years.

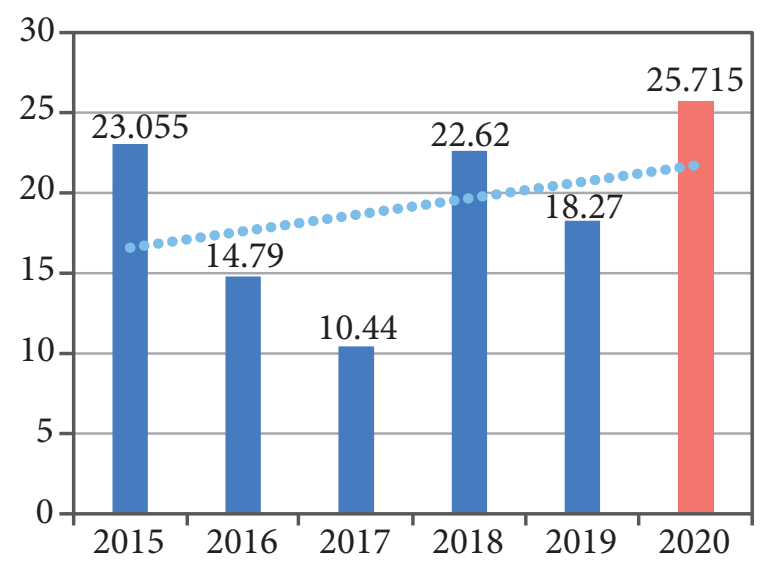

Figure 2. Revenue from enrollment of international students in 2015-2020 ( $\mathrm{mln}$ rbs) Source: MIPT annual report on international admission for $2020 / 2021$

The number of fee-paying students is not the only indicator that reflects the positive effect of the system. Since the very day the MIPT was founded, it has been a center of attraction for the most talented students from all over Russia and the CIS countries. And in recent years there has been an increasing interest in the university from applicants from non-CIS countries. It should be noted that, despite the predictions, their share increased significantly in the year when the pandemic began (Fig. 3) - for the first time in 6 years it amounted to $39 \%$ - in other words, more than $1 / 3$ of the international admission.

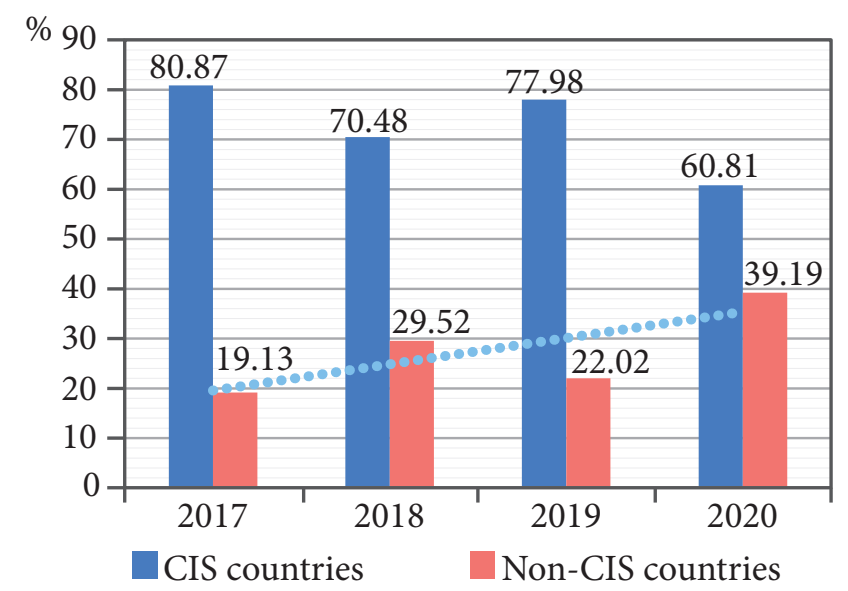

Figure 3. Distribution of students from CIS and non-CIS countries

Source: MIPT annual report on international admission for $2020 / 2021$ 
In addition, the percentage of international students has grown significantly in the overall number (up to $15.11 \%$ ) (Fig. 4).

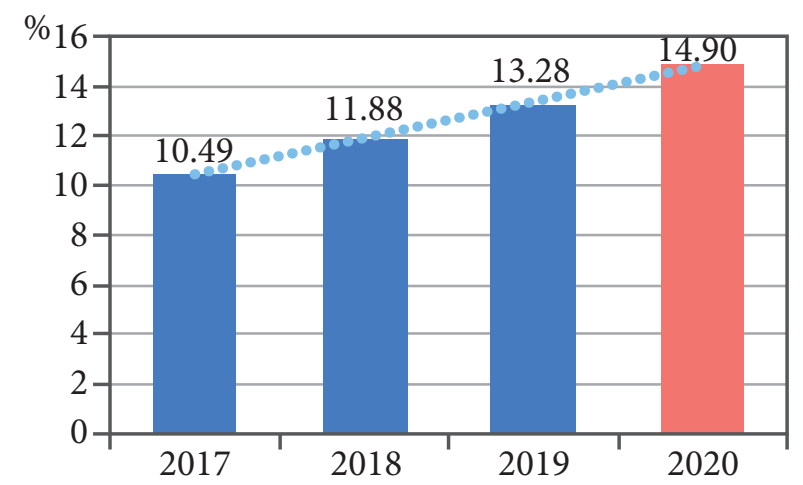

Figure 4. Growing percentage

of international students in the overall number of MIPT students (\%)

Source: MIPT annual report on international admission for $2020 / 2021$

To put this in context, at the universities of Tomsk region, this figure was $27 \%^{13}$, in the Higher School of Economics (St. Petersburg), which is considered as one of the most internationalized universities, $31 \%^{14}$; and in the University of

${ }^{13}$ RIA Novosti (Applicant's navigator): International admissions have increased at universities of Novosibirsk and Tomsk (In Russ.) Retrieved from: https://na.ria.ru/20200916/ studenty-1577336422.html

${ }^{14}$ Report on HSE University - St. Petersburg international work for 2019-2020 academic years.
Tyumen, 10\%. The Southern Federal University ${ }^{15}$ came closest to the MIPT of the percentage of students from non-CIS countries - 33\%.

The system has been actively used during the university's admissions campaign in 2020/21. In this period, more than 50 events were created and conducted (around 20 full exams with oral and written parts). The International Department conducted testing sessions for students from nonCIS countries as well as tests at the MIPT's preparatory department for international students.

Due to the lockdown, many internal exams, retaking exams, contests and tests were carried out by different departments of the universities with the help of the proctoring system (in total more that 70 events).

\section{Economic model of the MIPT proctoring system}

At the MIPT, Members of the faculty and staff act as proctors at examinations. Thus, the MIPT does not bear any variable costs while conducting the exams, which is a definitive advantage in comparison with the majority of similar systems, where each exam has to be paid for separately, depending on the number of applicants and proctors involved.

15 "On the priority tasks in the field of internationalization of the university" (report of the vice-rector for project-innovation activities and international cooperation of SFedU, 2020)

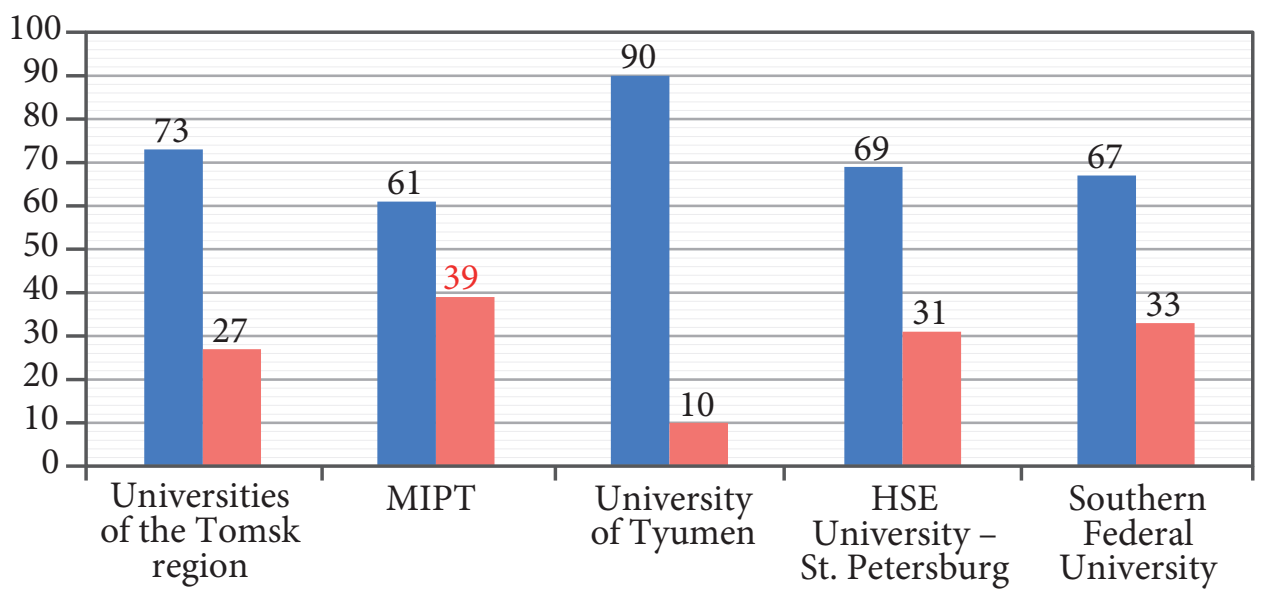

- Percentage of students from CIS countries
Percentage of students from non-CIS countries

Figure 5. Distribution of students from CIS and non-CIS countries in Russian universities (\%)

Source: MIPT annual report on international admission for 2020/2021, RIA Novosti (Applicant's navigator): 'International admissions have increased at universities of Novosibirsk and Tomsk' (dated 16.09.2020), Report on the HSE University St. Peterburg international work for 2019-2020 academic years, 'On the priority tasks in the field of internationalization of the university' (Report of the Vice-Rector on Project Innovation Work and International Cooperation SFedU, 2020) 
We have compared the MIPT proctoring system with one of the most popular international systems - Proctorio and Examinity and the most popular system in Russia - Examus. These systems were chosen because of the similarity of their features: each of them can be used to conduct an exam with a live online proctor (that is, with real-time human monitoring). This format appears to be the most transparent and is capable of completely replacing the face-to-face examination format (D'Souza \& Siegfeldt, 2017, Kuh et al., 2005)).

The systems may be compared according to the two groups of criteria:

1. Operational - the criteria that characterize the quality of the system, its accessibility and the transparency of the examination process, such as being a browser-based platform (that is, there is no need for installing a special program or a desktop application); user support 24/7 and the possibility to conduct exams with a live online proctor;

2. Financial - these criteria include the costs of each event for the university, the dependence of the cost on the number of participants, and the need to enter into a contract with external counterparties. Moreover, it is important to take into account the possibility of re-configuring the system for free to adjust it to the university's needs or for a specific event (in other words, free customization).

The results of this comparison are presented in Table 1.

As indicated in Table 1, the ability to work in a browser is provided only by the Russian systems such as Examus and the MIPT system. Foreign systems require an installation of a special program (or in some cases could be integrated into some types of universities LMS software), which means that Russian systems are more accessible for international applicants. 24/7 user support is available in all the options, except for the MIPT's system. However, this is just a formal distinction during the exams and the days before their start and several hours after, the MIPT staff also provide support on a 24-hour basis, so in fact technical support is not available only on the days when there are no exams.

Financially, the MIPT system wins on all three points, in fact, the costs of operating the resulting product are negligible for the university and, most importantly, the system is flexible and can be easily adjusted.

For instance, the MIPT acted as a partner of Moscow Center of Quality of Education and the Department of Education of Moscow in conducting pre-professional exams for two groups: academic (scientific and technological) and engineering. $15 \mathrm{MIPT}$ professors acted as proctors. The total number of exams was 16 and total number of events, more than 30 . The pre-professional exams were organized by the Moscow Center of the Quality of Education with the financial support of the Department of Science and Higher Education of Moscow (the total number of participants - 340). Furthermore, at the request of the Federal Agency of the Commonwealth of Independent States Affairs, Compatriots Living Abroad and International Humanitarian Cooperation (Rossotrudnichestvo), the MIPT held exams in its proctoring system for students seeking to obtain quotas for education in the Russian Federation in mathematics and physics in Moldova, Armenia, Uzbekistan and Abkhazia. The assignments were developed by MIPT professors. The staff of the International Department acted as proctors (the total number of participants: in mathematics - 502, in physics - 301).

Comparison of the most popular products for online proctoring in Russia and other countries

\begin{tabular}{|l|c|c|c|c|c|c|}
\hline \multicolumn{1}{|c|}{ System } & $\begin{array}{c}\text { Browser-based } \\
\text { application }\end{array}$ & $\begin{array}{c}\text { Ability to } \\
\text { conduct an } \\
\text { exam with a live } \\
\text { proctor }\end{array}$ & Customization & $\begin{array}{c}\text { User support } \\
\mathbf{2 4 / 7}\end{array}$ & $\begin{array}{c}\text { Variable costs } \\
\text { (Depending on } \\
\text { the number of } \\
\text { applicants) }\end{array}$ & $\begin{array}{c}\text { Payment for } \\
\text { the services } \\
\text { of an external } \\
\text { counterparty }\end{array}$ \\
\hline Examus & Yes & Yes & Paid & Always & Yes & Yes \\
\hline MIPT proctoring & Yes & Yes & Free of charge & $\begin{array}{c}\text { Only during } \\
\text { examinations }\end{array}$ & No & No \\
\hline Proctorio & No & Yes & Paid & Always & $\begin{array}{c}\text { Yes (with a live } \\
\text { online proctor) }\end{array}$ & Yes \\
\hline Examinity & No & Yes & No & Always & $\begin{array}{c}\text { Yes (with a live } \\
\text { online proctor) }\end{array}$ & Yes \\
\hline
\end{tabular}

Source: Comparison is based on the analysis of the companies' websites offering the most popular solutions for proctored exams: https://ru.examus.net/, https://proctorio.com/, https://www.examity.com/ 


\section{Conclusion}

In this article we examined the experience of developing and applying an in-house online proctoring system at the Moscow Institute of Physics and Technology and analyzed the effect of this system on the results of the 2020 international admissions campaign. Furthermore, the experience of applying the ready-to-use online proctoring systems in Russia and abroad was analyzed and compared. The study showed that not only does the MIPT system perform on a par with ready-to-use solutions in terms of quality, accessibility for users and transparency of conducted exams but it is also much more profitable from the economical point of view since, unlike its counterparts, it does not bear variable costs and does not need any significant additional investment while using it.
During the pandemic, when the demand for education overseas dropped dramatically all over the world, the MIPT managed to ensure successful recruitment of international students and increase the profit from their admission by $40 \%$. The overall cost of the system for the university was about 2.5 million rubles, while the difference in the revenue from the enrollment of fee-paying overseas students was 7.5 million between 2020 and 2021 (the pandemic year). In its current state (without any crucial improvements requiring significant financial investment) the system will be able to function for several more years. Thus, we may assume that the system has shown its full financial efficiency and that other universities and organization can benefit from the MIPT's experience of developing its own online proctoring system.

\section{References}

Alessio, H.M., \& Messinger, J.D. (2021). Faculty and Student Perceptions of Academic Integrity in Technology-Assisted Learning and Testing. Frontiers in Education, 6, doi: 10.3389/feduc.2021.629220

Anderson, T. (2008). The Theory and Practice of Online Learning ( $2^{\text {nd }}$ Edition $)$. Albert: Athabasca University Press.

Arno, S., Galassi, A., Tommasi, M., Saggino, A., \& Vittorini, P. (2021). State-of-the-Art of Commercial Proctoring Systems and Their Use in Academic Online Exams. International Journal of Distance Education Technologies, 19(2), 41-60. doi: 10.4018/IJDET.20210401.0a3

toum, Y., Chen L., Liu, A.X., Hsu, St.D.H., \& Liu, X. (2017). Automated online exam proctoring. IEEE Transactions on Multimedia, 19(7), 1609-1624. doi: 10.1109/TMM.2017.2656064

Chung, E., Subramaniam, G., \& Christ Dass, L. (2020). Online learning readiness among university students in Malaysia amidst Covid-19. Asian Journal of University Education, 16(2), 45-58. doi: 10.24191/ajue.v16i2.10294

Collis, B., \& Moonen, J. (2004). Flexible Learning in a Digital World ( $2^{\text {nd }}$ ed.), London: Routledge and Falmer. doi: 10.1080/0268051022000048228

Corrigan-Gibbs, H., Gupta, N., Northcutt, C., Cutrell, E., \& Thies, W. (2015). Deterring Cheating in Online Environments. ACM Transactions on Computer-Human Interaction, 22(6). doi: 10.1145/2810239

D'Souza, K.A., \& Siegfeldt, D.V. (2017). A conceptual framework for detecting cheating in online and take-home exams: Conceptual framework for detecting cheating in exams. Decision Sciences Journal of Innovative Education, 15(4), 370-391. doi: 10.1111/dsji.12140

Dawson, P. (2015). Five ways to hack and cheat with bring your own device electronic examinations. British Journal of Educational Technology, 12. doi: 10.1111/bjet.12246

Gourlay, L. (2021). There Is No 'Virtual Learning: The Materiality of Digital Education. Journal of New Approaches in Educational Research, 10(1), 57-66. doi: 10.7821/naer.2021.1.649

Graham, A. (2019). Benefits of online teaching for face-to-face teaching at historically black colleges and universities. Online Learning, 23(1), 144-163. doi: 10.24059/olj.v23i1.1435

Grajek, S., (2020). EDUCAUSE COVID-19 QuickPoll Results: Grading and Proctoring. EDUCAUSE Review. Retrieved from EDUCAUSE Research Notes: $\underline{\text { https://er.educause.edu/blogs/2020/4/ }}$ educause-covid-19-quickpoll-results-grading-and-proctoring\#fn3

Grande-de-Prado, M., Garcia-Penalvo, F.J., Corell Almuzara, A., \& Abella-Garcia, V. (2021). Higher Education assessment during COVID-19 pandemic. Campus Virtuales, 10(1), 49-58.

Huang, R.H., Liu, D.J., Guo, J., Yang, J.F., Zhao, J.H., Wei, X.F., Knyazeva, S., Li, M., Zhuang, R.X., Looi, C.K., \& Chang, T.W. (2020). Guidance on Flexible Learning during Campus Closures: Ensuring 
course quality of higher education in COVID-19 outbreak. Beijing: Smart Learning Institute of Beijing Normal University.

Jia, J.Y., \& He, Y.F. (2021). The design, implementation and pilot application of an intelligent online proctoring system for online exams. Interactive Technology and Smart Education, Vol. aheadof-print No. ahead-of-print. doi: 10.1108/ITSE-12-2020-0246

Johnson, J.B., Reddy, P., Chand, R., \& Naiker, M. (2021). Attitudes and awareness of regional Pacific Island students towards e-learning. International Journal of Educational Technology in Higher Education, 18(13). doi: 10.1186/s41239-021-00248-Z

Kharbat, F.F., \& Abu Daabes, A.S. (2021). E-proctored exams during the COVID-19 pandemic: A close understanding. Educ Inf Technol. doi: 10.1007/s10639-021-10458-7

Kitto, S., \& Saltmarsh, S. (2007). The production of 'Proper Cheating' in online examinations within technological universities. International Journal of Qualitative Studies in Education, 20(2), 151. doi: $10.1080 / 09518390600923792$

Klyagin, A.V., Abalmasova, E.S., Garev, K.V.., Gruzdev, I.A., Egorov, A.A., Zakharova, U.S., Kalinin, R.G., Kamaldinova, L.R., Karlov I.A., Korneeva, I.E., Makaryeva, A.Yu., Minaeva, E.A., Platonova, D.P., Semenova, T.V., Skokova, Yu.A., Terentyev, E.A., Frumin, I.D., Shwindt, A.N., \& Shibanova, E.Yu. (2020). Storm of the first weeks: how higher education stepped into the reality of the pandemic. Modern Education Analytics, 6 (36). (In Russ.). Retrieved from: https://ioe.hse. ru/data/2020/05/26/1551527214/\% D0\%A $1 \%$ D0\%90\%D0\%9E \%206(36) \%D1\%8D \% D0\%BB\%D0\%B5\%D0\%BA\%D1\%82\%D1\%80\%D0\%BE\%D0\%BD\%D0\%BD\%D1\%8B\%D0\%B9.pdf

Kuh, G.D., Kinzie, J., Schuh, J.H., \& Whitt, E.J. (2005). Assessing conditions to enhance educational effectiveness. San Francisco: Jossey-Bass.

Li, M., Luo, L., Sikdar, S., Nizam, N.I., Gao, S., Shan, H., Kruger, M., Kruger, U., Mohamed, H., Xia, L., \& Wang G. (2021). Optimized collusion prevention for online exams during social distancing. Ngj Science of Learning, 6(5), doi: 10.1038/s41539-020-00083-3

Linden, K., \& Gonzalez, P. (2021). Zoom invigilated exams: A protocol for rapid adoption to remote examinations. British Journal of Education Technology, 52(4), 1323-1337. doi: $\underline{10.1111 / b j e t .13109}$

Raman, R., Sairam, B., Veena, G., Vachharajani, H., \& Negungadi, P. (2021). Adoption of online proctored examinations by university students during COVID-19: Innovation diffusion study. Education and Information Technologies. doi: 10.1007/s10639-021-10581-5

Reedy, A., Pfitzner, D., Rook, L., \& Ellis, L. (2021). Responding to the COVID-19 emergency: student and academic staff perceptions of academic integrity in the transition to online exams at three Australian universities. International Journal for Education Integrity, 17(1). doi: 10.1007/ s40979-021-00075-9

Rumbley, L.E. (2020). Coping with COVID-19: International higher education in Europe. Amsterdam: The European Association for International Education (EAIE).

Shraim, K. (2019). Online examination practices in higher education institutions: Learners' perspectives. Turkish Online Journal of Distance Education, 185-196.

\section{Information about the author}

Anna D. Oykher - Deputy Director of the International Department, Moscow Institute of Physics and Technology (9 Institutsky per., Building 7, Dolgoprudny, Moscow Region, 141701, Russia); e-mail: anna.oykher@gmail.com

ARTICLE INFO: received June 5, 2021; accepted August 3, 2021

\section{Информация об авторе}

Ойхер Анна Дмитриевна - заместитель директора международного департамента, Московский физико-технический институт (141701, г. Долгопрудный, Московская обл., пер. Институтский, 9); e-mail: anna.oykher@gmail.com

ИНФОРМАЦИЯ О СТАТЬЕ: дата поступления 5 июня 2021 г.; дата принятия к печати 3 августа 2021 г. 